\begin{tabular}{l|l|l|l|l} 
Volume 1 & Issue 3 & October (2021) & DOI: 10.47540/ijias.v1i3.288 & Page: $200-207$
\end{tabular}

\title{
Effects of Poultry Biochar on Electrochemical Properties of an Alfisol and
}

\section{Vertisol of Northern Nigeria}

\author{
Onokebhagbe Victor Odiamehi ${ }^{1}$, Uzoma Kingsley Chinyere ${ }^{2}$, Lawal Mubarak ${ }^{3}$, Auwalu \\ Abubakar ${ }^{4}$, Habib Dahiru Wakili ${ }^{5}$ \\ 1,3,4,5 Department of Soil Science, Faculty of Agriculture, Federal University Dutse, Jigawa State, Nigeria \\ ${ }^{2}$ Department of Soil Science and Meteorology, College of Crop and Soil Sciences, Michael Okpara, Nigeria \\ Corresponding Author: Onokebhagbe Victor Odiamehi; Email: victor.o@fud.edu.ng
}

\begin{tabular}{|c|c|}
\hline A R T I C LE INFO & A B S T R A C T \\
\hline $\begin{array}{l}\text { Keywords: Biochar, Cation Exchange } \\
\text { Capacity, Electrical Charge, Point Zero } \\
\text { Charge, Surface Potentials. }\end{array}$ & $\begin{array}{l}\text { This study was aimed to know the effects of biochar on charge properties of an } \\
\text { Alfisol and Vertisol of semi-arid soils of Northern Nigeria. A laboratory experiment } \\
\text { was conducted to determine the effects of biochar on point zero charge of soils. An } \\
\text { experiment was laid out in a complete randomized design and consisted of two }\end{array}$ \\
\hline $\begin{array}{ll}\text { Received } & : 04 \text { July } 2021 \\
\text { Revised } & : 13 \text { October } 2021 \\
\text { Accepted } & : 15 \text { October } 2021\end{array}$ & $\begin{array}{l}\text { factors; } 2 \text { soil types and biochar at } 4 \text { levels giving a total of } 8 \text { treatment } \\
\text { combinations with } 3 \text { replications each. The results obtained from the study showed } \\
\text { that the } \mathrm{pH} \text { in } \mathrm{KCl} \text { of the incubated soils ranged from } 7.3 \text { to } 7.4 \text { and } 7.6 \text { to } 7.9 \text { for } \\
\text { the Alfisol and Vertisol; } 7.5 \text { to } 7.7 \text { and } 7.9 \text { to } 8.3 \mathrm{pH} \text { in } \mathrm{H}_{2} \mathrm{O} \text {, was obtained for the } \\
\text { Alfisol and Vertisol respectively. Electrical conductivity obtained ranged from } 3.22 \\
\text { to } 4.72 \text { and } 2.88 \text { to } 4.21 \mathrm{dS} \mathrm{m} \mathrm{m}^{-1} \text { for Alfisol and Vertisol respectively. Electrical } \\
\text { potentials ranged from }-19.70 \text { to }-35 \text { and }-31.45 \text { to }-63.04 \text { for the Alfisol and } \\
\text { Vertisol respectively. The Point Zero Charge of soils correlated positively with the } \\
\text { properties of the soils and the biochar rates. The addition of biochar to soils } \\
\text { modified the PZC, increased the pH, electrical conductivity (ECe), and cation } \\
\text { exchange capacity (CEC) of the soils. }\end{array}$ \\
\hline
\end{tabular}

\section{INTRODUCTION}

Retention and availability of plant nutrients are some major problems in agricultural soils of the semi-arid regions of northern Nigeria, due to high temperature, leaching, loss of surface soil due to erosion, wide range of $\mathrm{pH}$ variations, and low organic matter content. This inadvertently affects the nature and composition of the soil colloids (Ibrahim et al., 2014). The surfaces of soil colloids are largely dominated by negative charges which aid in the attraction and retention of cations in the soils. The predominance of these charges largely influences the cation exchange capacity of soils. These charges are generated by the adsorption and desorption potential of the ions, particularly $\mathrm{H}^{+}$and $\mathrm{OH}^{-}$hence the colloids are called per charge $\mathrm{pH}-$ dependent (Zhang et al., 1991). The study of the electrical charges of colloidal particles (organic and inorganic) is necessary for the understanding of different physical and chemical reactions that occur in the soil because most electrochemical reactions influence fertility and plant nutrition (Fontes et al., 2001; Kononova, 2006).

Point of Zero Charge (PZC) is an electrochemical characteristic of great importance in soils with a predominance of $\mathrm{pH}$-dependent charges, affecting soil properties such as flocculation, dispersion, cation exchange, and nutrient availability, among others (Fontes et al., 2001; Appel et al., 2003; Fontes and Alleoni, 2006). "The point of Zero Charge (PZC) is corresponding to the soil $\mathrm{pH}$ value in which the balance between the positive and negative charges is zero. i.e., if it is negative, $\mathrm{pH}>\mathrm{PZC}$, and positive, if $\mathrm{pH}<\mathrm{PZC}$ or zero, if $\mathrm{pH}=\mathrm{PZC}$ (Appel et al., 2003).

Biochar affects crop yield indirectly by improving soil physical properties (bulk density, water holding capacity, soil aggregation and 
permeability, saturated hydraulic conductivity, etc), chemical properties (e.g. nutrient retention and availability), and biological properties (Glaser et al. 2002; Lehmann and Rondon, 2006; Yamato et al. 2006; Chan et al. 2007, Asai et al. 2009). Therefore, this study was carried out to determine the effects of poultry biochar on electric potential and Point Zero Charge of two benchmark soils (Vertisols and Alfisols) of Jama'are (Bauchi State) and Dutse (Jigawa states) both of the Sudan savanna agroecological zones of Nigeria.

\section{METHODS}

\section{Description of Study Area}

The two Semi-arid soils used for this study are classified as Alfisol and Vertisol (Voncir et al., 2008). The Alfisol for this study was collected from the Teaching and Research Farm of Federal University Dutse, (Lat 11 $\mathrm{O}_{46}$ '39" $\mathrm{N}$ and Long $9 \mathrm{O}_{20}{ }^{\prime}$ ”' E) Jigawa State, Nigeria while the Vertisol was sampled from Jama'are in Jama'are Local Government area (Lat $11^{\circ} 66{ }^{\prime} 6^{\prime}, ' \mathrm{~N}$ and Long 9094'7' E) of Bauchi State, Nigeria. Both study areas are semi-arid in nature and fall within the Sudan savannah agro-ecological zone of Northern Nigeria. The study areas are fertile arable land, which most tropical cereal crops can adapt. The Sudan savannah vegetation zone is also made up of vast grazing lands suitable for livestock production. The soil samples were air-dried, crushed, sieved, and stored in clean polythene bags and labeled. The soil samples were analyzed for their physiochemical parameters using standard analytical procedures.

\section{Biochar Production}

Biochar used in this study was produced from poultry droppings using an electric muffle furnace (SX-4-10) at a constant temperature of $400^{\circ} \mathrm{C}$ for 30 minutes. The $\mathrm{pH}$ of the biochar was determined in water and in $0.01 \mathrm{M} \mathrm{KCl}$ solution using a 1: 2.5 biochar: water ratio as described by Gee and Bauder (1986) on two-way equilibration with a buffer solution at $\mathrm{pH} 4.0,7.0$ and 10.0.

\section{Incubation Study}

The experiment was laid out in a complete randomized design (CRD). Fifty grams of soil was incubated with 50,60, 70, and 80 grams of biochar on a weight per weight basis. The soils and biochar doses combinations were made on weight by weight bases. Eight treatments were obtained from soils
(Alfisol and Vertisol) and biochar combinations. The treatments were replicated 3 times and incubated for one month. Under incubation, each treatment was watered to soil water holding capacity using deionized water once in a week. Constant stirring of soil and the biochar materials was carried to get a uniform composition.

\section{Point of Zero Charge Determination}

The point zero charge (PZC) of the soil biochar treatment combinations was estimated by the equation outlined by Keng and Uehara (1974) and adopted by Chaves et al., (2016) in the estimation of $\mathrm{PZC}$ and surface electrical potential:

$\mathrm{PZC}=(2 \times \mathrm{pHKCl})-\mathrm{pHH}_{2} \mathrm{O} \ldots .$.

With $\mathrm{pH}$ values obtained, $\triangle \mathrm{pH}$ of the treatments were also calculated using the formula:

$\Delta \mathrm{pH}=\mathrm{pHKCl}-\mathrm{pHH}_{2} \mathrm{O} \ldots \ldots$.

The value of the surface electrical potential $\left(\Psi_{0}\right)$ expressed in $\mathrm{mV}$ was calculated using the Nernst equation, simplified by Chaves et al., (2016) as follows:

$\Psi_{0}=59.1\left(\mathrm{PZC}-\mathrm{pHH}_{2} \mathrm{O}\right) \ldots \ldots$

\section{Soil Analysis}

Particle size analysis was determined using Bouyoucos hydrometer method as described by Jaiswal (2003). pH determination was carried out according to the procedure outlined by Agbenin (1995). Electrical conductivity was measured in a 1:2.5 fresh soil-water suspension with a glass electrode meter according to the procedure described by Jackson (1962). Total Nitrogen was determined using the Kjeldhal procedure as described by Bremner (1996). The exchangeable bases were determined according to the ammonium acetatate procedure described by Anderson and Ingram (1993). Cations exchange capacity (C.E.C) was determined by the summation method as outlined by Anderson and Ingram (1993). Organic matter content was determined using the WalkleyBlack procedures (FAO, 1974). Available phosphorus was determined colorimetrically by the ammonium molybdate blue method using ascorbic acid as a reducing agent (Reeuwijk, 1993).

\section{Statistical Analysis}

The data obtained were subjected to descriptive statistics and one-way analysis of variance (ANOVA). Mean separation was carried out using the least significant difference (LSD) as 
outlined by Gomez and Gomez (1984). Pearson correlation analysis was used to determine the relationships between the electrochemical properties of the biochar-incubated soils and the measured PZC. All statistical analysis was carried out using SAS software package version 9.1.

\section{RESULTS AND DISCUSSION}

\section{Soil physical and chemical parameters}

Table 1 shows the properties of the soils used for the study. The soil texture is sandy clay loam for Dutse and clay loam for Jama'are. The soil reaction in Table 1 ranged from 4.9-5 in Dutse and 4.4-4.8 in Jama'are, indicating slight acidity to neutrality. Electrical conductivity (ECe) values of 1.08 and $1.06 \mathrm{dSm}^{-1}$ were obtained for Dutse and Jama'are Organic matter contents of the soils, Dutse (1.034 g $\left.\mathrm{kg}^{-1}\right)$ and Jama'are $\left(2.68 \mathrm{~g} \mathrm{~kg}^{-1}\right)$ were below the critical level of $20 \mathrm{~g} \mathrm{~kg}^{-1}$ hence low. Total $\mathrm{N}$ contents of 0.6 and $0.8 \mathrm{~g} \mathrm{~kg}^{-1}$ of the soils obtained from Dutse and Jama'are were low as the values were below the critical level of $1.5 \mathrm{~g} \mathrm{~kg}^{-1}$ and hence crop responses to fertilizer applications are likely. Available $P$ values of 11.02 and $27.9 \mathrm{mg} \mathrm{kg}^{-1}$ for Dutse and Jama'are soils respectively The cation exchange capacity of Dutse soil was low (3.53 C mol $(+) \mathrm{kg}^{-1}$ ) while the value of $6.47 \mathrm{C} \mathrm{mol}_{(+)} \mathrm{kg}^{-1}$ was medium for Jama'are as against the critical values of $<6$ (low), 6-12 (medium) and $>12$ (high). Exchangeable bases $\mathrm{Ca}^{2+}$ was 1.82 and 4.01C mol $\left.{ }_{(+)} \mathrm{kg}^{-1}\right) ; \mathrm{Mg}^{2+} 0.92$ and $1.44 \mathrm{C} \mathrm{mol}_{(+)} \mathrm{kg}^{-}$ ${ }^{1} ; \mathrm{K}^{+}, 0.18$ and $0.42 \mathrm{C} \mathrm{mol}_{(+)} \mathrm{kg}^{-1}$ and $\mathrm{Na}^{+}, 0.58$ and $0.60 \mathrm{C} \mathrm{mol}_{(+)} \mathrm{kg}^{-1}$ for Dutse and Jama'are soils, respectively.

Table 1. Physical and Chemical Properties of the Study Soils

\begin{tabular}{|c|c|c|}
\hline Soil Properties & Alfisol & Vertisol \\
\hline \multicolumn{3}{|l|}{ Particle Size Distribution } \\
\hline Clay $(\%)$ & 22 & 32 \\
\hline Silt (\%) & 14 & 30 \\
\hline Sand $(\%)$ & 64 & 38 \\
\hline Textural Class & Sandy clay loam & Clay loam \\
\hline $\mathrm{pH}_{(\mathrm{H} 2 \mathrm{O})}$ & 5 & 4.8 \\
\hline $\mathrm{pH}_{(\mathrm{kcl} 2)}$ & 4.9 & 4.4 \\
\hline $\mathrm{EC}\left(\mathrm{dSm}^{-1}\right)$ & 1.06 & 1.08 \\
\hline Organic Carbon $\left(\mathrm{g} \mathrm{kg}^{-1}\right)$ & 4.9 & 5.95 \\
\hline Organic Matter $\left(\mathrm{g} \mathrm{kg}^{-1}\right)$ & 1.03 & 2.68 \\
\hline Total Nitrogen $\left(\mathrm{g} \mathrm{kg}^{-1}\right)$ & 0.6 & 0.8 \\
\hline Available $\mathrm{P}\left(\mathrm{mg} \mathrm{kg}^{-1}\right)$ & 11.02 & 27.9 \\
\hline Exchangeable $\mathrm{Ca}\left(\mathrm{C} \mathrm{mol}_{(+)} \mathrm{kg}^{-1}\right)$ & 1.82 & 4.01 \\
\hline Exchangeable $\mathrm{Mg}\left(\mathrm{C} \mathrm{mol}_{(+)} \mathrm{kg}^{-1}\right)$ & 0.92 & 1.44 \\
\hline Exchangeable $\mathrm{K}\left(\mathrm{C} \mathrm{mol}_{(+)} \mathrm{kg}^{-1}\right)$ & 0.18 & 0.42 \\
\hline Exchangeable $\mathrm{Na}\left(\mathrm{C} \mathrm{mol}_{(+)} \mathrm{kg}^{-1}\right)$ & 0.58 & 0.60 \\
\hline $\mathrm{SEB}\left(\mathrm{Cmol}_{(+)} \mathrm{kg}^{-1}\right)$ & 3.53 & 6.47 \\
\hline
\end{tabular}

SEB: Sum of Exchangeable Bases

\section{Chemical Properties of Biochar}

The chemical properties of the biochars are presented in Table 2. The $\mathrm{pH}$ of the biochar was slightly alkaline $(\mathrm{pH}=8)$. Mineral analysis showed that the biochar has various amounts of inorganic elements. The amounts of the mineral elements contained in the biochar (Table 2) were higher than the amounts of elements contained in the soil samples (Table 1) used for the laboratory study thereby signifying their potential as alternative sources to fertilizers. 
Table 2. Chemical Properties of Poultry Biochar

\begin{tabular}{|l|c|}
\hline Parameters & Values \\
\hline $\mathrm{pH}$ & 8 \\
\hline Total Nitrogen $\left(\mathrm{g} \mathrm{kg}^{-1}\right)$ & 31.1 \\
\hline Total $\mathrm{P}\left(\mathrm{g} \mathrm{kg}^{-1}\right)$ & 52.02 \\
\hline Exchangeable bases $\left(\mathrm{cmol} \mathrm{kg}^{-1}\right)$ & \\
\hline $\mathrm{K}$ & 25.46 \\
\hline $\mathrm{Ca}$ & 59.75 \\
\hline $\mathrm{Na}$ & 14.07 \\
\hline $\mathrm{Mg}$ & 38.4 \\
\hline
\end{tabular}

The nitrogen content of the biochar was 31.01 the soils increased with increasing rates of biochar. $\mathrm{g} \mathrm{kg}^{-1}$. Total $\mathrm{P}$ was $52.02 \mathrm{~g} \mathrm{~kg}^{-1}$ respectively for poultry biochar. The $\mathrm{P}$ content obtained from the biochar was high when compared to soil P. Lower $\mathrm{K}$ value of $25.46 \mathrm{cmol}_{(+)} \mathrm{kg}^{-1}$ was reported for the biochar. Calcium $\left(59.75 \mathrm{cmol}_{(+)} \mathrm{kg}^{-1}\right)$ in the biochar was higher than the $\mathrm{Ca}$ in soils as shown in Table 1. Significant $(p<0.05)$ differences were observed among the ECe means obtained from the soils. The ECe values of the biochar infused soil samples as shown in Table 3 were significantly $(\mathrm{p}<0.05)$ different. Treatments with $80 \mathrm{~g}$ infused biochar from both soils had the highest EC values of 4.21 Effect of Poultry Biochar on Properties of Dutse and Jama'are Soils and 4.72. Wide variation in ECe was also observed as the values vary from $0.39-4.18 \mathrm{dSm}^{-1}$.

Table 3 shows the effect of biochar on charge properties of the soils. . Electrical conductivities of

Table 3. Effect of Poultry Biochar on Electrical Properties of Alfisol and Vertisol

\begin{tabular}{|c|c|c|c|c|c|c|}
\hline Treatment & $\mathrm{pH} \mathrm{KCl}$ & $\mathrm{pHH}_{2} 0$ & $\mathrm{ECe}\left(\mathrm{dSm}^{-1}\right)$ & $\Delta \mathrm{pH}$ & $\mathrm{PZC}$ & $\Psi_{0}(\mathrm{mV})$ \\
\hline & & & Alfisol & & & \\
\hline $\mathrm{AlfBC}_{50}$ & 7.3 & 7.5 & $3.22^{\mathrm{b}}$ & -0.13 & 7.1 & -23.64 \\
\hline $\mathrm{AlfBC}_{60}$ & 7.3 & 7.6 & $3.92^{\mathrm{ab}}$ & -0.30 & 7.0 & -35.40 \\
\hline $\mathrm{AlfBC}_{70}$ & 7.4 & 7.5 & $4.16^{\mathrm{ab}}$ & -0.17 & 7.2 & -19.70 \\
\hline $\mathrm{AlfBC}_{80}$ & 7.4 & 7.7 & $4.72^{\mathrm{a}}$ & -0.27 & 7.1 & -31.46 \\
\hline & & & Vertisol & & & \\
\hline $\mathrm{VerBC}_{50}$ & $7.7^{\mathrm{ab}}$ & 7.9 & $2.88^{\mathrm{bc}}$ & $-0.33^{\mathrm{abc}}$ & 7.3 & -35.46 \\
\hline $\mathrm{VerBC}_{60}$ & $7.6^{\mathrm{b}}$ & 8.2 & $2.70^{\mathrm{c}}$ & $-0.53^{\mathrm{c}}$ & 7.1 & -63.04 \\
\hline $\mathrm{VerBC}_{70}$ & $7.6^{\mathrm{b}}$ & 8.0 & $3.51^{\mathrm{ab}}$ & $-0.47^{\mathrm{bc}}$ & 7.1 & -55.16 \\
\hline $\mathrm{VerBC}_{80}$ & $7.9^{\mathrm{a}}$ & 8.3 & $4.21^{\mathrm{a}}$ & $-0.43^{\mathrm{abc}}$ & 7.4 & -51.22 \\
\hline
\end{tabular}

Means with the same letters were not significantly different at $\mathrm{p}<0.05$.

Table 4. Pearson Correlation Coefficients $(r)$ and Significance of Linear Relationship Between PZC and Electrochemical Properties of Biochar Incubated Soils.

\begin{tabular}{|c|c|c|c|c|}
\hline \multirow{2}{*}{ Factors } & \multicolumn{2}{|c|}{ Alfisol } & \multicolumn{2}{c|}{ Vertisol } \\
\cline { 2 - 5 } & $r$ & Significance level & $r$ & Significance level \\
\hline ECe & -0.13 & NS & 0.62 & ${ }^{*}$ \\
\hline $\mathrm{pH}$ & 0.91 & $* * *$ & 0.84 & $* * *$ \\
\hline$\Psi_{0}$ & 0.91 & $* * *$ & 0.81 & $* *$ \\
\hline
\end{tabular}

$*, * *, * * *$ are significance level of $<0.05,<0.01$ and $<0.001$, respectively;

NS: not statistically significant. 
Correlation Coefficient between PZC and Some Selected Properties of Biochar Incubated Soils

The result of the estimated relationship between PZC and electrochemical properties of the soils are shown in Table 4. The result showed that the $\mathrm{pH}$ and $\Psi_{0}$ had a strong correlation with the PZC of the Alfisol and Vertisol under the experimental conditions. The $r$ value of 0.91 showed that $91 \%$ change in PZC in the Alfisol was influenced by $\Delta \mathrm{pH}$ and $\Psi_{0}$. For the Vertisol, Pearson $r$ value of $0.62,0.84$ and 0.81 revealed that PZC strongly correlated with ECe, $\mathrm{pH}$ and $\Psi_{0}$. This showed that variations in the PZC of the Vertisol were highly influenced by the three parameters mentioned above. Electrical conductivity (ECe) had no effects on the PZC of the Alfisol as shown in Table 4. This was contrary to the results obtained from the Vertisol, which showed a significant correlation between the ECe and the Vertisol.

\section{Effects of Biochar on Electrochemical Properties of Soils}

The application of poultry biochar to the soils increased the PZC of the soils. The PZC of both soils was within the same range. Higher $\mathrm{pH}$ values were obtained from the biochar treated soils concerning the native $\mathrm{pH}$ values of the soils though there was no corresponding increase in $\mathrm{pH}$ values with increase biochar rates. The high $\mathrm{pH}$ values obtained from the biochar were similar to the range of $\mathrm{pH}$ values of biochars obtained by Chan and $\mathrm{Xu}$ (2009). This tends to be in contrast with the result obtained by Lehmann (2007) which stated that the $\mathrm{pH}$ of soils increased with an increase in biochar rates and Chaves et al. (2016) who also obtained a similar linear increase in $\mathrm{pH}$ with an increase in biochar rates in Ultisol, Oxisol, Entisols.

The increase in $\mathrm{pH}$ values of the biocharincubated soils could be linked to the dissociation reactions of functional groups containing oxygen on the surfaces of the biochar and these are consistent with the findings by Marta et al., (2019). Also, the liming effects of biochar could have played a role in an increase in soil $\mathrm{pH}$, which could reduce cationic attraction and mobility due to reduced competition between the $\mathrm{H}^{+} /$metal cations for the exchange sites on the biochar and soil surfaces (Beesley et al., 2011).

Similarly, negative electric potential $\left(\Psi_{0}\right)$ values as shown in this study were due to the increase in $\mathrm{pH}$ of the biochar incubated soils as well as the low PZC values (Table 3). Higher negative charges were obtained from the Vertisol after incubation. The number of surface charges could be directly linked to the clay mineral contents of the soils. Charges have been known to vary from positive under acidic conditions to negative under strongly alkaline conditions. With the effects of the biochar on the $\mathrm{pH}$ of the soils as observed from the study, it is logical to assume that the negative potential values obtained from the study were directly influenced by the modification of the soils' $\mathrm{pH}$ by the biochar. This corresponds with the observation made by Chaves et al. (2006) who stated that "this negative sign and magnitude of $\Psi_{0}$ were directly influenced by the related magnitude of the $\Delta \mathrm{pH}$ ". The increase in negative charges could be directly linked to the aging of the biochar as well as the dissociation of functional groups and activity of PDI (potential determining ions, e.g., $\mathrm{H}^{+}$and $\mathrm{OH})$ during the incubation period. This is similar to the findings of Cheng et al. (2006) that over time with aging, biochar in the soil and the occurrence of abiotic oxidation reaction on its surface, especially for the formation of carboxyl groups tend to increase the negative charge consequently leading to an increase in the CEC.

The negative $\Delta \mathrm{pH}$ values indicated a predominance of negative charges in the two soils samples. In this case, the cation exchange capacity (CEC) of these soils exceeded the anion exchange capacity (AEC) of the incubated soils in the modified $\mathrm{pH}$ conditions. However, the magnitude of $\Delta \mathrm{pH}$ decreased with increasing biochar rates and as well, showed a reduction of CEC. The cation exchange capacity increase is primarily attributed to the negative charge on the outer surface of the biochar, which arises from the dissociation of functional groups (Cheng et al. 2006). Anegbe et al. (2015) also demonstrated that cation exchange capacity increased with the increased doses of biochar and lapse of time from the application of material into the soil. On the other hand, Kuzyakov et al. (2009) reported that biochar introduced into the soil undergoes an aging process in the presence of air, water, and microorganism activity, which in turn leads to the formation of stable complexes of trace element and biochar. 
Strong positive correlations were identified for the ECe (Vertisol), $\mathrm{pH}$ and $\Psi_{0}$. This indicated that increased variations in PZC were strongly influenced by change in $\mathrm{ECe}, \mathrm{pH}(\Delta \mathrm{pH})$ and surface electrical potential $\left(\Psi_{0}\right)$. A high $\mathrm{pH}$ in biochar can be linked to the high content of alkaline minerals contained in the biochar. The charge development in the soils could as well be linked to the dissociation of the functional groups contained in the biochar. This also largely depends on the $\mathrm{pH}$ of the biochar, as dissociation of different functional groups varies with the $\mathrm{pH}$ of the biochar material.

\section{CONCLUSION}

This study showed that the properties of the semi-arid soils were influenced by the addition of the biochar. The chemical properties of Alfisol and Vertisol obtained from Dutse and Jama'are were enhanced by the application of poultry waste biochar. The addition of biochar to the soils modified and decreased the values of the $\Delta \mathrm{pH}, \Psi_{0}$, CEC but raised the PZC of the soils. This study has also revealed the importance of the role played by biochar due to the increase in negative charges that will help in plant nutrients (cations) adsorption and retention thereby increasing the fertility status of the soil. Therefore the addition of biochar to soils will lead to positive responses by plants due to improved fertility of the soils. Hence knowledge of the effects of biochar on $\mathrm{pH}$ and electric charges of soils will contribute immensely to understanding its impact on soil fertility and plant nutrient retentions in soils, especially when used as soil amendments. It is therefore recommended that biochar amendments applied to the soil should be allowed to decay over some time before cultivating such soil as this helps to lower the PZC of the soil thereby improving soil fertility.

\section{REFERENCES}

1. Abdu, N. \& Etiene, U. A. (2015). Fifteen-year fallow altered the dynamics of soil phosphorus and cationic balance of a savannah Alfisol. Archives of Agronomy and Soil Science, 61: 645- 656.

2. Agbenin, J. O. (1995). Laboratory manual for Soil and Plant Analysis (Selected Methods and
Data Analysis). Institute for Agricultural Research, Zaria, Nigeria.

3. Anderson, J. M. \& Ingram, J. S. I. (1993). In Tropical soil biology and fertility: A handbook of methods. CAB International, Wallingford, $U$. K. Pp 68-71.

4. Anegbe, B., Okuo, J. M., Ewekay, E. O. \& Ogbeifun D. E. (2015). Fractionation of leadacid battery soil amended with biochar. Bayero Journal of Pure and Applied Sciences, 7(2): 3643.

5. Appel C., Ma L. Q., Rhue, R. D. \& Kennelley, E. (2003). Point of zero charge determination in soils and minerals via traditional methods and detection of electroacoustic mobility. Geoderma, 113:77-93.

6. Asai, H., Samson, B. K., Stephan, H. M., Songyikhangsuthor, K., Homma, K., Kiyono, Y., Inoue, Y., Shiraiwa, T. \& Horie, T. (2009). Biochar amendment techniques for upland rice production in Northern Laos: 1. Soil physical properties, leaf SPAD and grain yield. Field Crops Research, 111: 81-84.

7. Beesley, L., Moreno-Jimenez, E., GomezEyles, J., Harris, E., Robinson, B. \& Sizmur, T. (2011). A review of biochars' potential role in the remediation, revegetation and restoration of contaminated soils. Environmental Pollution, $\mathrm{xxx}: 1-14$.

8. Brady, N. C. \& Weil, R. C. (2013). The nature and properties of soils. (14th revised ed.). Noida, India: Dorling Kindersley Pvt. Ltd. 350p.

9. Bremner, J. M. (1996). Nitrogen-Total. In A. Miller, \& D. Keeny, Methods of soil analysis (pp. 595-624). Madison, USA: American Society of Agronomy.

10. Chan, K. Y., Van Zwieten, L., Meszaros, I., Downie, A. \& Joseph, S. (2007). Agronomic values of greenwaste biochar as a soil amendment. Australian Journal of Soil Research. 45: 629-634.

11. Chaves, L. H. G., Mendes, J. S. \& Iede de Brito Chaves. (2016). Effects of poultry biochar on electrochemical properties of electronegative 
soils. International Journal of Current Research, 8 (11): 40834-40837.

12. Cheng, C. H., Lehmann, J., Thies, J. E., Burton, S. D., \& Engelhard, M. H. (2006). Oxidation of black carbon by biotic and abiotic processes. Organic Geochemistry. 37, 1477-1488.

13. FAO. (1974). The Euphrates Pilot Irrigation Project. Methods of soil analysis, Gadeb Soil Laboratory (A laboratory manual). Food and Agriculture Organization, Rome, Italy.

14. Fontes, M. P. F. Camargo, O. A. \& Sposito, G. (2001). Eletroquímica das partículas coloidais e sua relação com a mineralogia de solos altamente intemperizados. Sci. Agric. 58 (3): 627-646.

15. Fontes, M. P. F. \& Alleoni, L. R. F. (2006). Electrochemical attributes and availability of nutrients, toxic elements, and heavy metals in tropical soils. Sci. Agric, 63 (6): 589-608.

16. Gaskin, J. W., Steiner, C., Harris, K., Das, K. C., \& Bibens, B. (2008). Effect of low temperature pyrolysis conditions on biochars for agricultural use. Transitional ASABE 51: 2061-2069.

17. Gee, G. W. \& Bauder, J. W. (1986). Particle size analysis. In A. a. SSSA, In Methods of soil analysis, Part 1, 2nd ed (pp. 383-411). Madison, WI: Agronomy Monogram, 9.

18. Glaser, B., Lehmann, J. \& Zech, W. (2002). Ameliorating physical and chemical properties of highly weathered soils in the tropics with charcoal: A review Biology and Fertility of Soils 35: 219-230.

19. Gomez, K. A. \& Gomez, A. A. (1984). Statistical procedure for agricultural research. (2ed.). John Wiley and Sons, New York, U.S.A. pp.: 680 .

20. Ibrahim, Y. E., Nuradeen, A. M. \& R. A. Abubakar. (2014). Factors affecting soil quality maintenance in Northern Katsina State, Nigeria. Science World Journal, 9 (4): 39-45.

21. Jackson, M. L. (1962). Soil Chemical Analysis. Prentice-Hall, Englewood Cliffs, NJ, USA.

22. Jaiswal, P. C., (2003). Soil, Plant and Water Analysis. Kalyani Publishers, New Delhi.
23. Keng, J. C. W. \& Uehara, G. (1974). Chemistry, mineralogy and taxonomy of Oxisols and Ultisols. Soil and Crop Science Society of Florida Proceedings, 33:119-26.

24. Kononova, M. M. (2006). Organic matter and soil fertility. Soviet Soil Science, 16:71-86.

25. Kuzyakov, Y., Subbotina, I. \& Chen, H., Bogomolova, I., Xu, X., (2009). Black carbon decomposition and incorporation into soil microbial biomass estimated by $14 \mathrm{C}$ labeling. Soil Biology and Biochemistry, 41: 210-219.

26. Lehmann J, Gaunt, J. \& Rondon, M. (2006). Bio-char sequestration in terrestrial ecosystems - A review. Mitigation and Adaptation Strategies for Global Change, 11:403-27.

27. Lehmann, J. (2007). Bio-energy in the black. Fronted Ecological Environment. 5, 381-387.

28. Malgwi, W. B., Ojanuga, A. G., Chude, V. O., Kparmwang, T. \& Raji, B. A.. (2000). Morphological and physical properties of some soils at Samaru, Zaria, Nigeria. Nigerian Journal of Soil Research, 1: 58-64.

29. Marta, C., Zofia, S. \& Boguta, P. (2019). Impact of biochar on physicochemical properties haplic luvisol soil under different land use: A plot experiment. Agronomy, 9 (531): 1-16.

30. Onokebhagbe, O. V., Abdu, N. \& Santuraki, H. A. (2018). Residual effects of biochar on dry matter yield of grain amaranths (Amaranthus cruentus L.) grown on Alfisols of Nigerian Northern Guinea and Sudan savanna agroecologies. Dutse Journal of Agriculture and Food Security, 5 (1): 97-108.

31. Reeuwijk, V. (1993). Procedures for soil analysis; Technical paper No.9. Fourth Edition. International soil reference and information centre (ISRIC).

32. Voncir, N., Mustapha, S., Tenebe, V. A., Kumo, A. L. \& Kushwaha, S. (2008). Content and profile distribution of extract Zinc ( $\mathrm{Zn})$ and some physiological properties of soil along a toposequence at Bauchi, Northern Guinea Savannah of Nigeria International Journal of soil science 3:62-68. 
33. Yamato, M., Okimori, Y., Wibowo, I. F., Anshori, S. \& Ogawa, M. (2006), Effects of the application of charred bark of Acacia mangium on the yield of maize, cowpea and peanut, and soil chemical properties in South Sumatra, Indonesia. Soil Science and Plant Nutrition, 52 (6): 489-495.

34. Zhang, F. S., Zhang, X. N. \& Yu, T. R. (1991). Reactions of hydrogen ions with variable charge soils: Ion mechanisms of reaction. Soil Science, 151:436-43. 